\title{
IMMOBILIZATION OF Bacillus subtilis E6-5 PROTEASE AND COMMERCIAL PROTEASE IN NANOFIBRILS CONTAINING DIFFERENT AMINO ACIDS
}

\author{
Baran Enes GULER, Elif DEMIRKAN*, Tuba SEVGİ \\ Faculty of Arts and Science, Department of Biology, Bursa Uludağ University, Bursa, TURKEY
}

Cite this article as:

Guler B.E., Demirkan E., Sevgi T. 2020. Immobilization of Bacillus subtilis E6-5 Protease and Commercial Protease in Nanofibrils Containing Different Amino Acids. Trakya Univ J Nat Sci, 21(1): 39-45, DOI: 10.23902/trkjnat.633788

Edited by:

Mustafa Yamac

*Corresponding Author:

Elif Demirkan

edemirkan@uludağ.edu.tr

\section{ORCID ID:}

orcid.org/0000-0002-5292-9482

Key words:

Immobilization

Electrospinning

Protease

Reusability

\begin{abstract}
In this study, polyamide 6 polymer surfaces that have a high surface area were produced by electrospinning method with the participation of Glycine, Tyrosine and Glutamic acid amino acids, and lyophilized Bacillus subtilis E6-5 protease and commercial protease enzymes were immobilized on nanofibrils. Enzyme reusability were investigated. The immobilization efficiencies of the enzymes were approximately between 50-55\%. In studies with lyophilized Bacillus protease, glutaraldehyde activated PA6 nanofibrils and glutaraldehyde unactivated PA6 nanofibrils were found to be more immobilized in the presence of Glutamic acid. Although the lyophilized protease enzyme immobilized on non-glutaraldehyde activated and activated surfaces has been used 4 times, the best functional stability has been achieved with 2 times use. In pure PA6/Glutamic acid nanofibrils, the immobilization yield of the two times used enzymes was found to be $38 \%$. In glutaraldehyde-activated PA6 nanofibrils, the PA6/Glutamic acid nanofibril surfaces were found to have $65 \%$ immobilization yield of the two repetitive used enzymes. The enzyme immobilization efficiency has been doubled by glutaraldehyde activation of the nanofibrils. In studies with commercial protease, the most functional stability was obtained for 3 repeated uses, although the enzyme was used 6 times on the non-glutaraldehyde activated nanofibril surfaces. The most successful immobilization was found in $58 \%$ of PA6 nanofibrils. In glutaraldehyde-activated PA6 nanofibrils, the enzyme was found to be used 6 times, but the functional stability was maintained as much as 4 times of repeated use.
\end{abstract}

Özet: Bu çalışmada, elektrospin yöntemiyle yüksek yüzey alanına sahip, glisin, tirozin ve glutamik asit aminoasitleri ile oluşturulmuş poliamid 6 polimer yüzeyler üretilmiş ve liyofilize Bacillus subtilis E6-5 proteaz ve ticari proteaz enzimleri nanofibriller üzerinde immobilize edilmiştir. Enzimlerin yeniden kullanılabilirliği araştırıldı. Enzimlerin immobilizasyon verimlilikleri yaklaşık olarak \% 50-55 arasındaydı. Liyofilize Bacillus proteazı ile yapılan çalışmalarda glutaraldehitle aktifleştirilmiş PA6 nanolifler ve glutaraldehitle aktifleştirilmeyen PA6 nanoliflerde glutamik asit aminoasidi varlığında immobilizasyonun daha başarılı olduğu saptanmıştır. Glutaraldehit ile aktifleştirilmemiş ve aktifleştirilmiş yüzeylerde immobilize edilen liyofilize proteaz enziminin 4 kez kullanımı olmasına rağmen, en iyi işlevsel stabilite $2 \mathrm{kez}$ kullanım ile elde edilmiştir. Saf PA6/glutamik asit nanoliflerinde iki tekrarlı kullanım sonucu enzimin immobilizasyon verimi \% 38 olarak bulunmuştur. Glutaraldehitle aktifleştirilmiş PA6 nanoliflerde de PA6/glutamik asit nanolif yüzeyleri iki tekrarlı kullanım sonucu enzimin immobilizasyon verimi $\% 65$ olarak bulunmuştur. Nanoliflerin glutaraldehitle aktifleştirmesi sonucu enzim immobilizasyon verimi iki kat arttırılmıştır. Ticari proteaz ile yapılan çalışmalarda ise glutaraldehitle aktifleştirilmemiş nanolif yüzeylerde enzimin 6 kez kullanımı olmasına rağmen en işlevsel stabilite 3 tekrarlı kullanımda elde edilmiştir. En başarılı immobilizasyon verimi PA6 nanoliflerde \% 58 olarak bulunmuştur. Glutaraldehitle aktifleştirilmiş PA6 nanoliflerde de enzim 6 kez kullanım bulmuş fakat işlevsel stabilite 4 tekrarlı kullanıma kadar korunmuştur.

\section{Introduction}

The use of enzymes in a soluble or free form must be considered as wasteful because the enzyme generally cannot be recovered at the end of the reaction. Utilization of enzymatic reactions for the industrial processes have been restricted due to relatively high enzyme costs. Most of the industrial enzymatic processes are performed batchwise using soluble enzymes. In order to re-use enzymes after reactions and to increase their stability, their immobilizations using an insoluble carrier have been broadly studied (Chaplin 1990). Enzyme immobilization 
can currently be carried out in different ways such as adsorption, covalent binding, entrapment and encapsulation (Taher 2011). Physical adsorption has been selected among these immobilization methods by many researchers considering its easy applicability, ability to maintain the enzymatic activity and the lack of expensive costs and toxic waste products (Al-Zuhair 2007).

A large variety of nano-structured polymers such as nanofibrils, nanoparticles, silica, and nanotubes have been used as solid supports. Electrospun nanofibrils have great potential for enzyme immobilization (Wang 2009). Nanofibrils have a large number of applications which blended wound healing, energy generation and storage, filtration and enzyme immobilization. Polyamide 6 nanofibrils (PA6 NFs) are practical materials for enzyme immobilization studies as they are easily available (Chen 2005).

In this study, the immobilizations of the previously isolated novel Bacillus subtilis protease and commercial protease (ORBA Biochemistry, Istanbul) in nanofibers containing different amino acids were investigated. The reusability of the nanofiber was also tested.

\section{Materials and Methods}

\section{Bacterial Protease Production}

Production of Bacillus subtilis protease was performed in flasks containing a medium including) glucose 0.1 , peptone 1 , yeast extract $0.02, \mathrm{MgSO}_{4} 0.01$, $\mathrm{CaCl}_{2} 0.01$ and $\mathrm{K}_{2} \mathrm{HPO}_{4} 0.05$ (pH 7.0) (Qadar et al. 2009). Glucose was sterilized and added to the flasks separately. Overnight B. subtilis cultures in Nutrient Broth medium $(0.8 \% \mathrm{w} / \mathrm{v})$ with an optical density of 0.3 at $600 \mathrm{~nm}$ were inoculated at $1 \%$ in enzyme production media $(250 \mathrm{~mL}$ in $1000 \mathrm{~mL}$ Erlenmeyer flasks) and incubated at $37^{\circ} \mathrm{C}$ for $48 \mathrm{~h}$ in a shaking incubator at $150 \mathrm{rpm}$. After incubation, the cultures were centrifuged (6000 rpm, $10 \mathrm{~min}$ ) and the supernatants were used for lyophilization.

\section{Assay of protease activity}

Total protease activity was measured using a casein substrate by a modification of the Anson Method (Keay and Wildi 1970). $1 \mathrm{~mL}$ aliquot of the culture supernatant was mixed with $1 \mathrm{~mL} 0.05 \mathrm{M}$ phosphate buffer $-0.1 \mathrm{M}$ $\mathrm{NaOH}$ (pH 7,0 adjusted with phosphoric acid) containing $2 \%$ casein and incubated for $10 \mathrm{~min}$ at $37^{\circ} \mathrm{C}$. The reaction was stopped by adding $2 \mathrm{~mL} 0.4 \mathrm{M}$ Trichloroacetic acid. After 30 min stands at room temperature, the precipitate was removed by centrifugation $(6000 \mathrm{rpm}, 10 \mathrm{~min})$ and the optical density of the assays was measured at $660 \mathrm{~nm}$. A standard curve was generated using solutions of 0-60 $\mu \mathrm{g} / \mathrm{mL}$ Tyrosine. One unit of protease activity was defined as the amount of enzyme required to liberate 1 $\mu \mathrm{g} / \mathrm{mL}$ Tyrosine under the experimental conditions used.

\section{Lyophilization of Bacillus subtilis E6-5 protease}

The crude enzyme extract obtained as a result of 1000 $\mathrm{mL}$ production in the enzyme production medium was kept at $-20^{\circ} \mathrm{C}$ overnight. The frozen samples were lyophilized (CHRIST Alpha 2-4 LD plus). The lyophilization process was carried out at $-55^{\circ} \mathrm{C}$ and the enzyme sample was powdered. Powder samples were dissolved in pure water $(20 \mathrm{~mL})$ to be ready for use for immobilization.

Preparation of PA6/Amino acid NFs via
$\underline{\text { electrospinning method }}$

$15 \%(\mathrm{w} / \mathrm{v})$ of polyamide 6 was dissolved in formic acid via magnetic stirring in ambient conditions and directly electrospun into nanofibrous mat structure with a proper electrospinning procedure. $20 \%(\mathrm{w} / \mathrm{v})$ of Glycine, Glutamic acid, and Tyrosine amino acids were added to polyamide 6 nanofibrils. Schematic illustration of the electrospinning process is demonstrated in Fig. 1 (Demirkan et al. 2018).

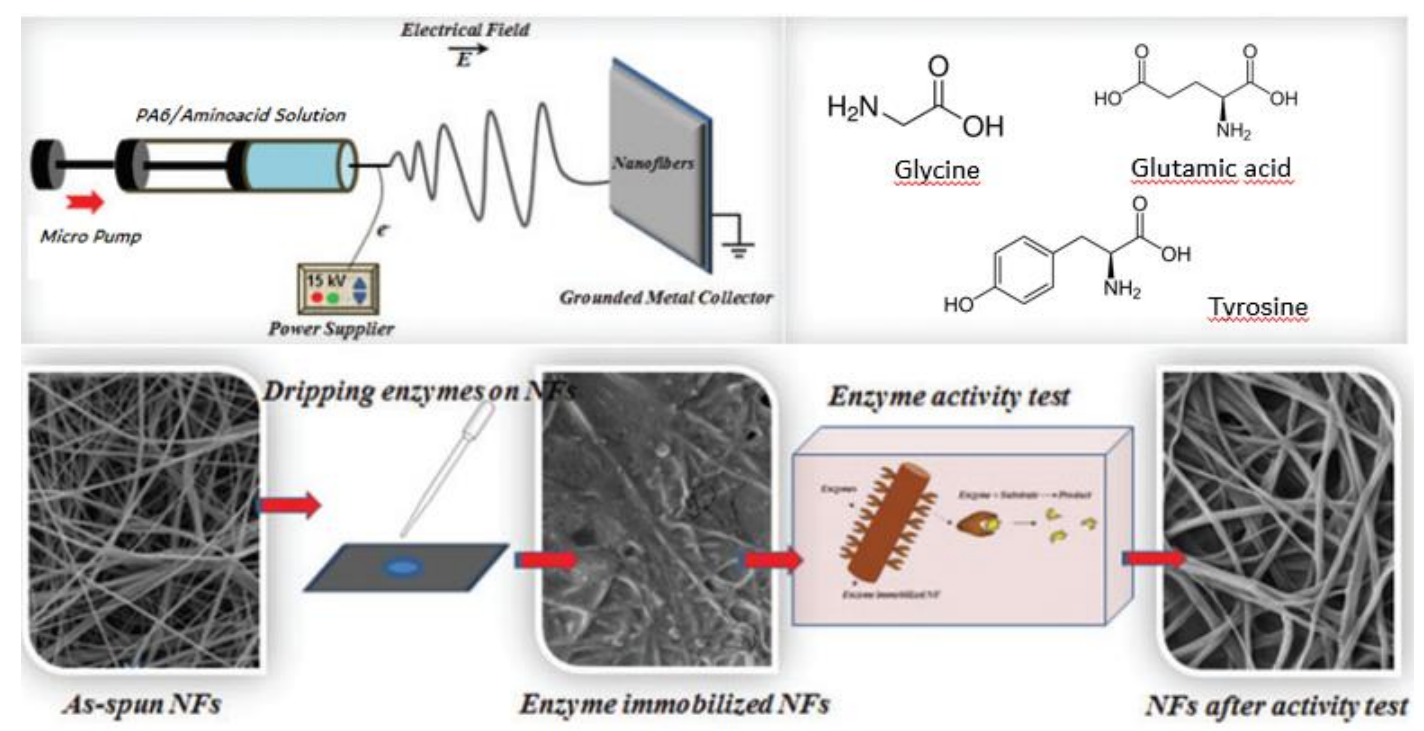

Fig. 1. Schematic illustration of the electrospinning process, chemical structures of amino acids, and the general concept of protease immobilization on as-spun nanofibrils and enzyme activity test (Demirkan et al. 2018). 
Final stock solution $(1 \mathrm{~mL})$ was loaded in a plastic syringe fitted with a stainless steel needle $(0.508 \mathrm{~mm}$ inner diameter). A metal collector was grounded and stayed in front of the needle where the polymer solution is fed. Flow rate, applied voltage and the distance were approximately $0.5 \mathrm{~mL} / \mathrm{h}, 15 \mathrm{kV}$, and $15 \mathrm{~cm}$, respectively. In order to obtain uniform NFs, these parameters were varied during the electrospinning process. Because of the applied voltage to the needle, polymer jet was ejected from the needle to grounded collector, the solvent was evaporated during the process, and dried NFs were collected on the grounded metal collector.

\section{Characterization of PA6/Amino acid NFs}

The morphologies of PA6/Amino acid NFs were analyzed using a ZEISS EVO 40 scanning electron microscope (SEM). In order to reduce charging during SEM analysis, samples were first placed on a SEM sample holder and coated with gold-palladium (about $100 \mathrm{~A}^{\circ}$ of thickness) using a BAL-TEC SCD005 sputter coater. Then the samples were set in the SEM chamber and SEM analyses were conducted. Acceleration voltage $(20 \mathrm{kV})$ was used for SEM analysis. The viscosity analyzes of the electrospinning solutions were performed with the Anton PaaR / MCR 302 instrument.

\section{Immobilization of enzymes on NFs}

The enzymes used in the experiments were immobilized on the nanofibril surface in two different ways. In the first immobilization process, $1 \mathrm{~mL}$ aliquots of enzyme solutions were directly dripped onto the asspun NF samples kept at room temperature for $12 \mathrm{~h}$ to immobilize enzymes on the NFs. Then, enzyme immobilized NFs were vigorously washed with pure water to remove excess free protease. In the second process, proteases were immobilized on GA-activated NFs for comparison in order to observe protease immobilization on the NFs via physical adsorption. For this purpose, GA was diluted with pure water, dropped on NFs and waited for 5 min before enzyme immobilization.

The immobilization efficiency was defined as;

$$
\text { Immobilization efficiency }(\%)=\left(\frac{a_{\text {imm }}}{a_{\text {free }}}\right) \times 100
$$

where $a_{i m m}$ is the activity of the immobilized enzyme $(\mathrm{U} / \mathrm{mL})$ and $a_{\text {free }}$ is the activity of the free enzyme $(\mathrm{U} / \mathrm{mL})$.

\section{Re-usability of the immobilized enzymes}

To determine the re-usability of the protease enzymes on the NFs surface, enzyme immobilized NFs were subjected to repeated hydrolysis reaction in activity assays for multiple times. Each run lasted for $20 \mathrm{~min}$, after which the polymers were separated, washed with pure water and stored at $4^{\circ} \mathrm{C}$ until the next use. The reaction medium was then replaced with fresh medium. Enzyme activity assays were sequential throughout the cycle. In order to prevent conditions affecting the enzyme, NFs were carefully removed when the first cycle was over and the second cycle was initiated and continued for other cycles. The activity in the first run was defined as $100 \%$.

\section{Statistical analysis}

All the experiments were performed in triplicate and values were expressed in terms of mean \pm SD (Standart Deviation).

\section{Results}

\section{SEM analysis of as-spun amino acid blended PA6 NFs}

Morphologies of as-spun amino acid blended PA6 NFs were evaluated via low and high magnification SEM imaging (Fig. 2). In order to attaine uniform NFs, electrospinning conditions (applied voltage, needle-tocollector distance, and solution flow rates) were varied during the electrospinning process.

The NFs produced by using only pure PA6 showed a uniform and oval structure (Fig. 2. A1, A2). In these pure PA6 NFs, the diameter of the nanofibril was between 50 and $150 \mathrm{~nm}$ (Fig. 2. A3). Glycine doped PA6 (Fig. 2. B1, B2) NHs showed a nanofibril diameter in a wide range from $150 \mathrm{~nm}$ to $800 \mathrm{~nm}$ (Fig. 2. B3). However, the diameters of $20 \%$ of the NFs were in the $400-450 \mathrm{~nm}$ range. No uniform structure was observed in NFs formed with the addition of Glycine and also bead formation occurred on NFs. PA6 (Fig. 2. C1, C2) NFs formed with Tyrosine addition were observed as uniform and oval. Nanofibril diameters were between 100-200 nm (Fig. 2. C3). Glutamic acid doped PA6 NFs showed much less bead formation than Glycine doped NFs and the resulting NFs were uniform (Fig. 2. D1, D2) and were mainly 100$200 \mathrm{~nm}$ in diameter (Fig. 2. D3).

Enzyme immobilization yield and stability
measurement

Proteases were immobilized on as-spun NFs via the physical adsorption method and held for $12 \mathrm{~h}$, and then enzyme activity measurements were performed. The immobilization efficiencies of the enzymes were approximately between 50-55 \%. Immobilized enzymes were washed with pure water and stored at $4^{\circ} \mathrm{C}$ until the next repetition. The initial activities were defined as $100 \%$. The immobilization efficiency of protease on as-spun PA6 and PA6/Amino acid NFs without treatment and with GA treatment was inspected by observing the number of reuse cycles of immobilized protease (Fig. 3). In studies with lyophilized Bacillus protease, glutaraldehyde activated PA6 NFs and glutaraldehyde unactivated PA6 NFs were found to be more immobilized in the presence of Glutamic acid. Although the lyophilized protease enzyme immobilized on non-glutaraldehyde activated and activated surfaces have been used 4 times, the best functional stability has been achieved with 2 times use. In pure PA6/Glutamic acid NFs, the immobilization yield of the enzymes used 2 times was found to be $38 \%$ (Fig. 3 A1). In glutaraldehyde-activated PA6 NFs, the PA6/Glutamic acid nanofibril surfaces were found to have $65 \%$ immobilization yield of the twice used enzymes (Fig. 3 A2). 

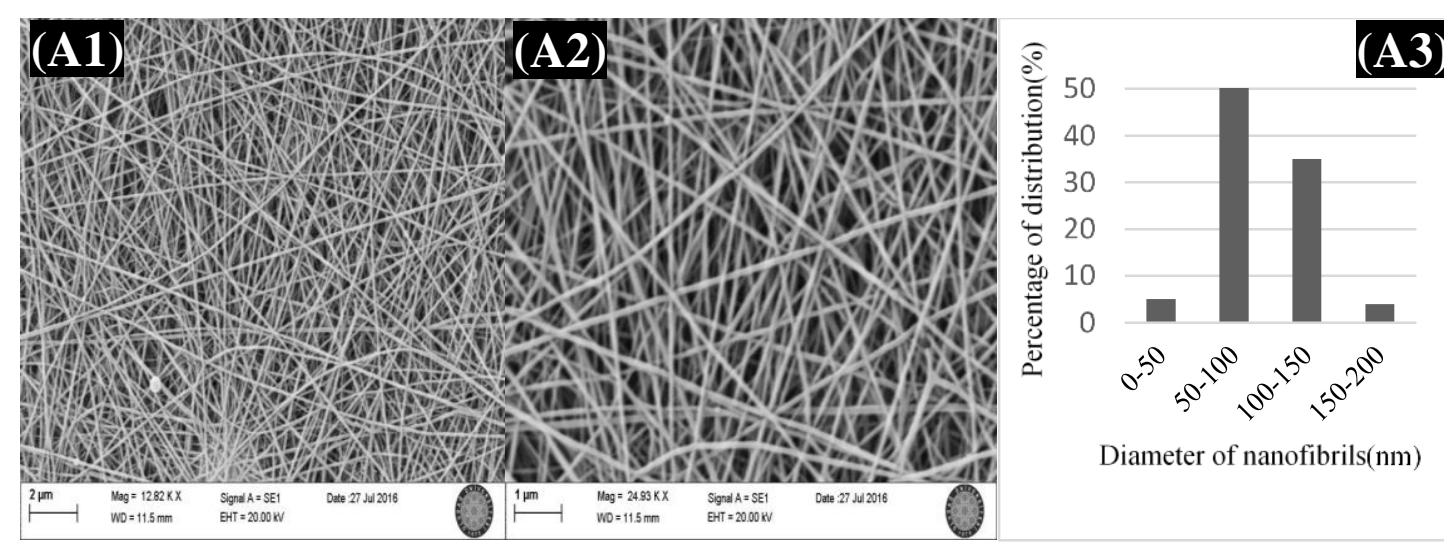

Diameter of nanofibrils(nm)
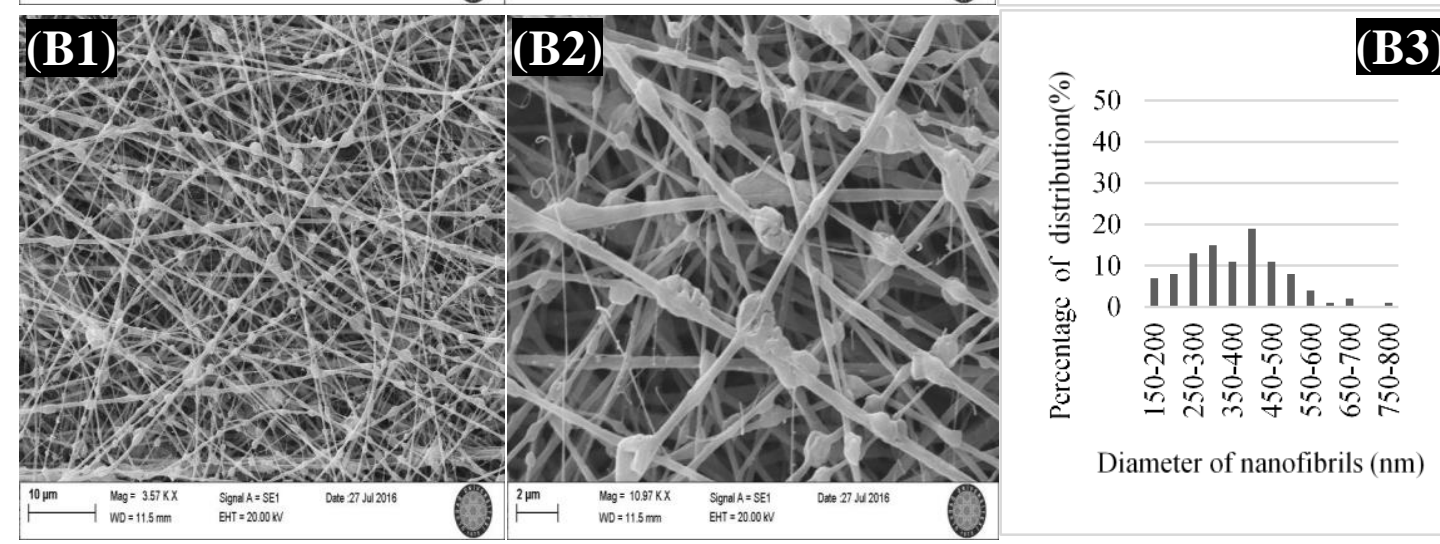

Diameter of nanofibrils ( $\mathrm{nm})$
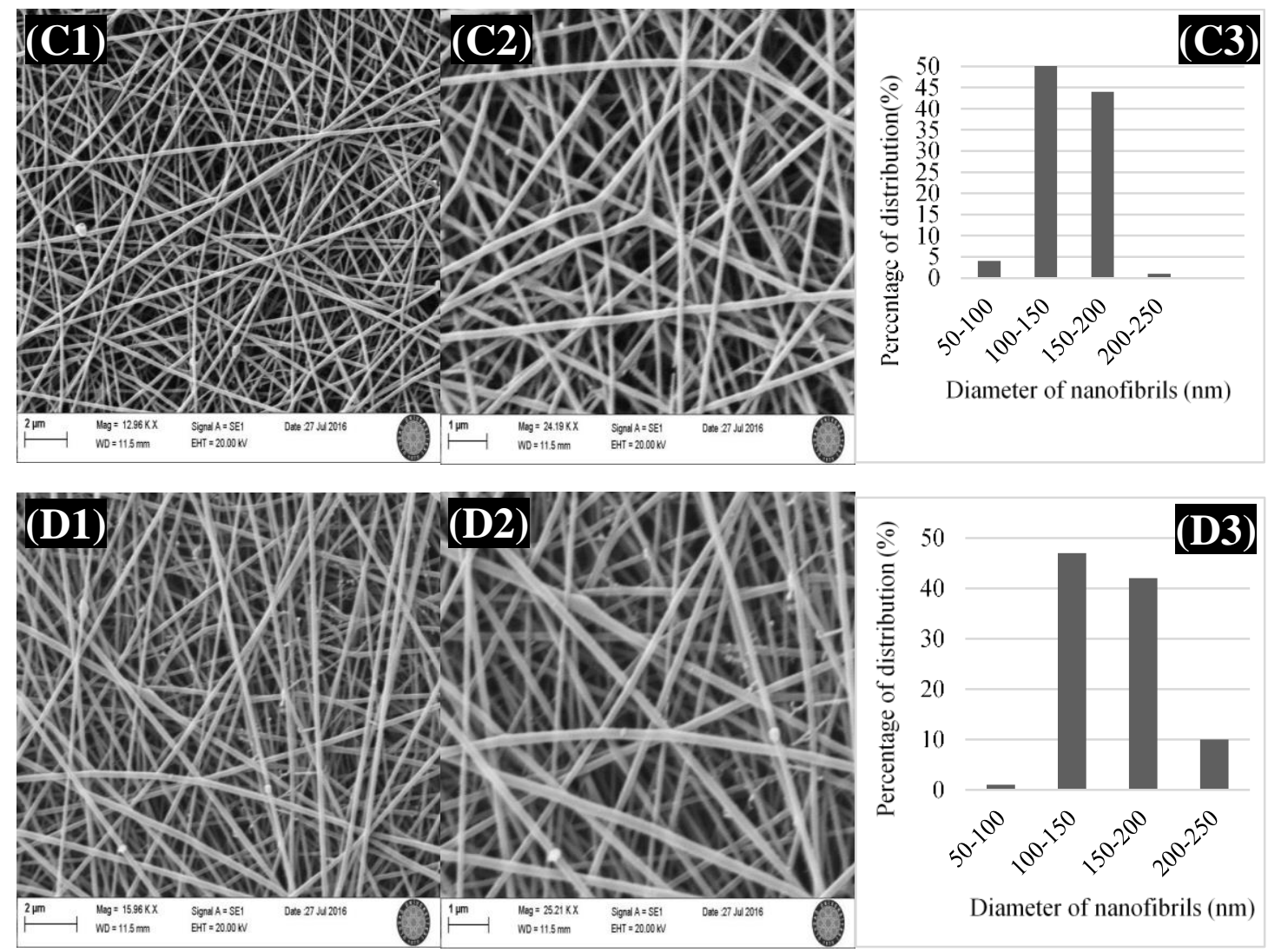

Fig. 2. SEM images of amino acid doped PA6NFs (A1, B1, C1, D1 with 15,96 KX magnification, A2, B2, C2, D2 with $25,22 \mathrm{KX}$ magnification): (A) Pure PA6, (B) PA6 / Glycine, (C) PA6 / Tyrosine, (D) PA6 / Glutamic acid. A3, B3, C3 and D3 show diameter values of NFs. 


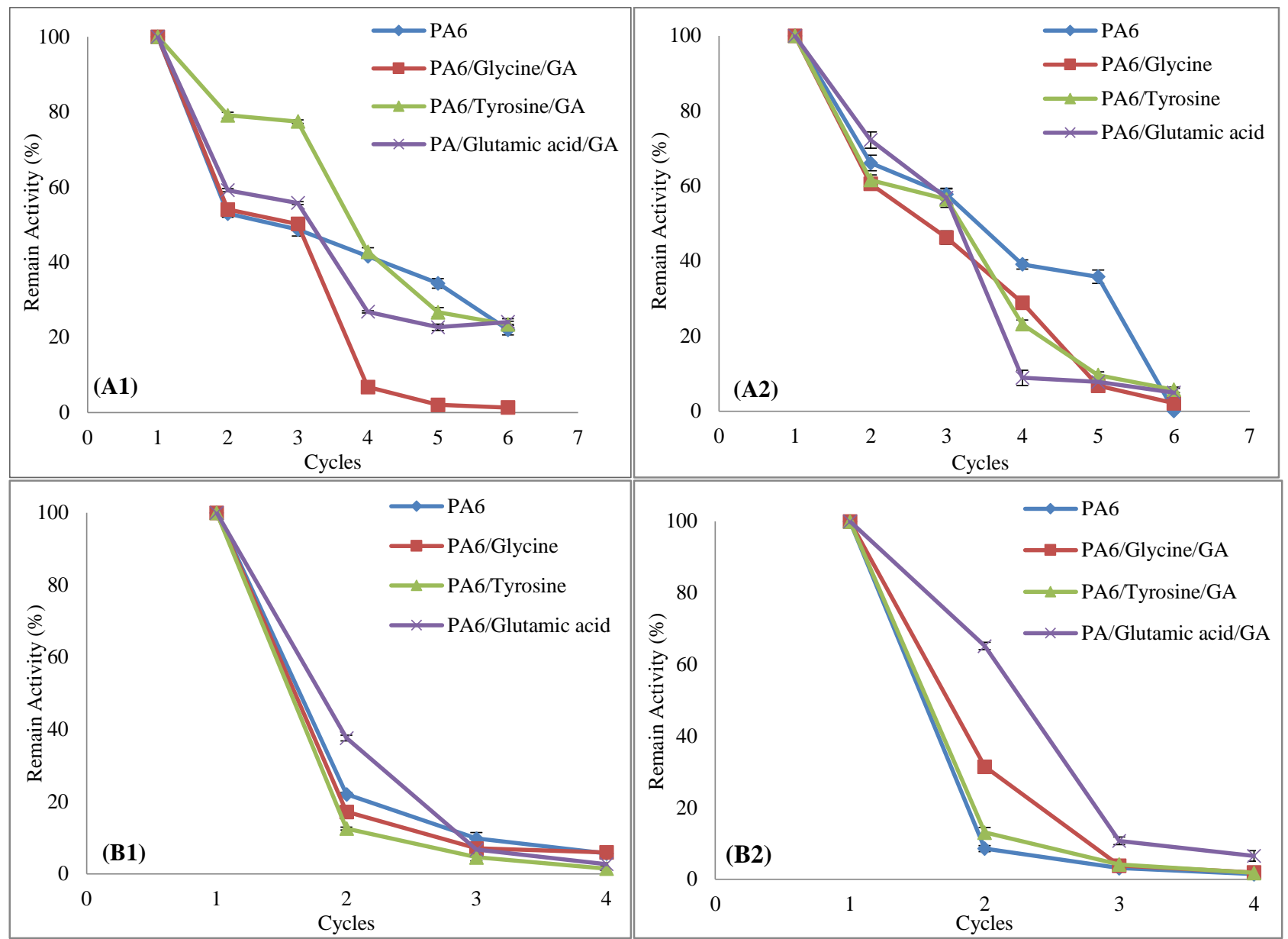

Fig. 3. Reusability of immobilized lyophilized and commercial protease enzyme. (A1) PA6/Amino acid NFs with lyophilized protease, (A2) PA6/Amino acid NFs coated with GA with lyophilized protease, (B1) PA6/Amino acid NFs with commercial protease (B2) PA6/Amino acid NFs with GA with commercial protease. All values are averages of results from triplicate trials; error bars indicate the SD values. PA6: polyamide 6; GA: glutaraldehyde; NF: nanofibril.

The enzyme immobilization efficiency has been doubled by glutaraldehyde activation of the NFs. In studies with commercial proteases, the most functional stability was obtained for 3 repeated uses, although the enzyme was used 6 times on the non-glutaraldehyde activated nanofibril surfaces. The most successful immobilization was found in $58 \%$ of PA6 NFs (Fig. 3 B1). In glutaraldehyde-activated PA6 NFs, the enzyme was found to be used 6 times, but the functional stability was maintained as much as 4 times of repeated use. The enzyme immobilization yield in PA6/Tyrosine NFs was $43 \%$ (Fig. 3 B2).

\section{Discussion}

Nanofibers stand out among the materials currently used in immobilization because it is widely accepted that nanoscale materials have large surface / volume ratios for enzyme loading. Electrospun NFs are promising supports for enzyme immobilization, as they have high porosity and low diffusion resistance that allow access to high specific surface areas and enzyme activity. These systems also provide easy reusability and potential applicability for continuous operations. Since PA6 is an easily available material, it is a suitable material for immobilization studies
(Chen et al. 2004). PA6 NFs have free $\mathrm{N}-\mathrm{H}$ and $\mathrm{C}=\mathrm{O}$ groups. A bond may be formed between these groups and the carboxy and amino groups of amino acids (Monsan et al. 1975). In this study, PA6 NFs were prepared via an electrospinning process with the participation of Glycine, Tyrosine and Glutamic acid amino acids. When SEM images are examined, as in the case of pure NFs obtained in oval and uniform, Tyrosine and Glutamic acid doped NAs are also oval and uniform, but uniform structure was not observed in Glycine NFs and bead formation occurred. With the addition of amino acid, there was no obvious negative effect on the NF structure, but only too much bead formation on the Glycine NF, and less bead formation on Glutamic acid NF occurred.

Lyophilized B. subtilis E6-5 protease and commercial protease were immobilized on these NFs. As a result of immobilization of lyophilized enzymes on pure PA6/amino acid NFs, after 2 cycle of usage, enzyme activity was maintained at $38 \%$ in the presence of PA6/Glutamic acid complex. In pure PA6 NF, PA6/Glycine and PA6/Tyrosine complexes, dramatic enzyme losses were detected after 2 cycle. In studies with commercial enzymes, enzyme immobilization studies 
with pure NFs were compared with studies with amino acid NFs, and it was found that enzyme activity (up to 60 $\%$ ) was retained in the third cycle in all three NFs with amino acids. Enzyme losses were observed in following cycles. Results in NF with Glutamic acid were better. This may be due to the benzene ring in the Tyrosine and the lack of an adequate attachment point in Glycine. Since Glutamic acid has 2 carboxyl groups, it may have made more connections with the enzyme.

The bifunctional agents can enhance the efficiency of favourable materials, such as glutaraldehyde, cyanogen bromide, and carbodiimide which are essential to stimulate the covalent binding between enzyme molecules and NFs (Chae 1998). Among these agents, glutaraldehyde is one of the most preferred agent commonly used as intermolecular crosslinking in proteins or to modify adsorbed proteins on aminated supports (Hwang 2004). The certain structure of glutaraldehyde on the support is yet under discussion, however, given the high stability of amino-glutaraldehyde bond, the formation of some kind of cycle seems to be a likely possibility (Migneault 2004). Since it is used as glutaraldehyde activating (cross-linking) agent in immobilization studies, it was also used in this study. As a result of the application of lyophilized Bacillus enzyme to pure PA6 and PA6/aminoacid NFs that activated with glutaraldehyde (GA): very dramatic enzyme losses were detected in 2 cycles in the NFs with PA6/GA, PA6/Tyrosine/GA and PA6/Glycine/GA. The most successful enzyme immobilization efficiency was obtained with PA6/Glutamic acid/GA NFs. Glutaraldehydeactivated PA6/Glutamic acid complex retained $65 \%$ of its activity after 2 repeated use. The PA6/Glutamic acid complex, which was not activated by glutaraldehyde, maintained $38 \%$ of its activity after 2 repeated use. This showed that glutaraldehyde is important for this NF. In studies conducted with commercial enzymes, it was found that while more enzyme immobilization was provided in trials without glutaraldehyde, the reuse number was 3 . When glutaraldehyde was used, less enzyme immobilization occurred, but the number of re-use was 4 . In pure NF with gluteraldehyde, $50 \%$ enzyme immobilization was detected in 2 cycles. On the other hand, it has been determined that enzyme activity in nanofibers with amino acid and glutaraldehyde remained over $50 \%$ for 3 cycles. Especially in pure NF with gluteraldehyde and NF with Tyrosine/glutaraldehyde, it was determined that enzyme activity was preserved by $43 \%$. It was revealed that the addition of glutaraldehyde has an important role in NFs containing amino acids.

Glutaraldehyde may react with proteins by several means such as aldol condensation or Michael-type addition (Migneault et al. 2004). As a result of these discrepancies and the unique characteristics of Bacillus subtilis protease and the commercial protease, crosslinking procedures using glutaraldehyde are largely developed through empirical observation. The choice of the enzyme-glutaraldehyde ratio, as well as their final concentration, is critical because insolubilization of the enzyme must result in minimal distortion of its structure in order to retain catalytic activity. Glutaraldehyde can react with several functional groups of proteins, such as amine, thiol, phenol, and imidazole because the most reactive amino acid side-chains are nucleophiles (Habeeb and Hiramoto 1968). The concentrations of enzyme and glutaraldehyde must be carefully considered to obtain water-insoluble enzyme derivatives via crosslinking (Zaborsky 1973).

In their studies on the immobilization of the protease enzyme obtained from Conidiobolus macrosporus on polyamide, Tanksale et al. (2001) immobilized the enzyme to nanofibrils using $1.76 \%$ glutaraldehyde and reported yield was $58 \%$. If there is no overlap between the functional group of the glutaraldehyde molecule - $\mathrm{CHO}$ and the amino group of the amino acids used, the functional group (-CHO) of glutaraldehyde can be randomly bound to the amine groups or amino acid residues of the enzyme, which may cause a change in the enzyme configuration. In this case, the enzyme may decrease the function or the enzyme may be completely inactivated. In addition, the free amino group of the various amino acids that used, in the immobilization process can bind glutaraldehyde with the aldehyde group and prevent the enzyme from fully binding to the NF surfaces (Migneault et al. 2004). Study of immobilization of commercial protease enzyme on glutaraldehyde-free NFs showed that the highest activity was in the PA6/Glycine NFs. In terms of enzyme activity, PA6/Glycine was followed by pure PA6, PA6/Tyrosine and PA6/Glutamic acid NFs. Despite the high immobilization success of PA6/Glycine NFs in the first usage, pure PA6 NFs was found to be more efficient in preserving the activity. The success of immobilization of pure PA6 NFs was demonstrated by preserving $58 \%$ of their activities up to 3 repetitive uses. In the study conducted with commercial protease enzyme, the activity loss experienced by the enzyme was investigated up to 6 repetitions. In the study performed with PA6/amino acid NFs activated with glutaraldehyde, PA6/GA complex showed the highest activity considering the initial activities. The PA6/GA complex was followed by PA6/Glutamic acid/GA, PA6/ Glycine/GA and PA6/Tyrosine/GA complexes, respectively. Enzymes immobilized PA/Tyrosine/GA NFs were considered to be the most successful immobilization, with maintaining $43 \%$ of their activity up to 4 repetitions. Aykut et al. (2017) prepared cellulose monoacetate/polycaprolactone and cellulose monoacetate/ polycaprolactamand activated the surfaces with aldehyde groups for protease immobilization. They obtained $35.5 \%$ efficiency after eight reuses, and enzyme activities of about $23 \%$ were still observed even after nine reuses (both for GA-activated and inactivated, pure CMA NF samples). Immobilized enzymes are preferred over their native counterparts because of their potential for repetitive use. In addition, the reaction product is not contaminated with the enzyme and the immobilized enzyme has a longer half-life and predictable decay rate (Reshmi et al. 2006). Immobilization condition obtained in this study may find use in different fields of textile and food. 


\section{References}

1. Al-Zuhair, S., Ling, F.W. \& Jun, L.S. 2007. Proposed kinetic mechanism of the production of biodiesel from palm oil using lipase. Process Biochemistry, 42(6): 951960.

2. Aykut, Y., Sevgi, T. \& Demirkan, E. 2017. Cellulose monoacetate/polycaprolactone and cellulose monoacetate/polycaprolactam blended nanofibers for protease immobilization. Journal of Applied Polymer Science, 134(44): 45479.

3. Butt, K.Y., Altaf, A., Malana, M.A., Ghori, M.I. \& Jamil, A. 2018. Optimal production of proteases from Bacillus subtilis using submerged fermentation. Pakistan Journal of Life and Social Sciences, 16(1):15-19.

4. Chae, H.J., In, M.J. \& Kim, E.Y. 1998. Optimization of protease immobilization by covalent binding using glutaraldehyde. Applied Biochemistry and Biotechnology, 73(2-3): 195-204.

5. Chaplin, M.F. \& Bucke, C. 1990. Enzyme technology. CUP Archive.

6. Chen, H. \& Hsieh, Y.L. 2005. Enzyme immobilization on ultrafine cellulose fibres via poly (acrylic acid) electrolyte grafts. Biotechnology and Bioengineering, 90(4): 405-413.

7. Demirkan, E., Avci, T. \& Aykut, Y. 2018. Protease immobilization on cellulose monoacetate/chitosan-blended nanofibers. Journal of Industrial Textiles, 47(8): 20922111.

8. Gupta, R., Beg, Q., \& Lorenz, P. 2002. Bacterial alkaline proteases: molecular approaches and industrial applications. Applied Microbiology and Biotechnology, 59(1): 15-32.

9. Habeeb, A.F.S.A. \& R. Hiramoto. 1968. Reaction of proteins with glutaraldehyde. Archives of Biochemistry and Biophysics 126:16-26.

10. Hwang, S., Lee, K.T., Park, J.W., Min, B.R., Haam, S., Ahn, I.S. \& Jung, J.K. 2004. Stability analysis of Bacillus stearothermophilus L1 lipase immobilized on surfacemodified silica gels. Biochemical Engineering Journal, 17(2): 85-90.

11. Keay, L. \& Wildi, B.S. 1970. Proteases of the genus Bacillus. I. Neutral proteases. Biotechnology and Bioengineering, 12(2): 179-212.

12. Kim, W., Choi, K., Kim, Y., Park, H., Choi, J., Lee, Y. \& Lee, S. 1996. Purification and characterization of a fibrinolytic enzyme produced from Bacillus sp. strain CK 11-4 screened from Chungkook-Jang. Applied and Environmental Microbiology, 62(7): 2482-2488.

13. Kumar, R. \& Vats, R. 2010. Protease production by Bacillus subtilis immobilized on different matrices. New York Science Journal, 3(7): 20-24.
14. Kumar, V., Singh, D., Sangwan, P. \& Gill, P.K. 2014 Global market scenario of industrial enzymes. Industrial enzymes: Trends, scope and relevance. Nova Science Publishers, New York, 173-196.

15. Migneault, I., Dartiguenave, C., Bertrand, M.J. \& Waldron, K.C. 2004. Glutaraldehyde: behavior in aqueous solution, reaction with proteins, and application to enzyme crosslinking. Biotechniques, 37(5): 790-802.

16. Monsan, P., Puzo, G. \& Mazarguil, H. 1975. Étude du mécanisme d'établissement des liaisons glutaraldehyde protéines. Biochimie, 57, 1281-1292.

17. Qadar, S.A.U., Shireen, E., Iqbal, S. \& Anwar, A. 2009. Optimization of protease production from newly isolated strain of Bacillus sp. PCSIR EA-3. Indian Journal of Biotechnology, 8(3): 286-290.

18. Reshmi, R., Sanjay, G. \& Sugunan, S. 2006. Enhanced activity and stability of $\alpha$-amylase immobilized on alumina. Catalysis Communications, 7(7): 460-465.

19. Rao, M.B., Tanksale, A.M., Ghatge, M.S. \& Deshpande, V.V. 1998. Molecular and biotechnological aspects of microbial proteases. Microbiology and Molecular Biology Reviews, 62(3): 597-635.

20. Saallah, S., Naim, M.N., Lenggoro, I.W., Mokhtar, M.N., Bakar, N.F.A. \& Gen, M. 2016. Immobilisation of cyclodextrin glucanotransferase into polyvinyl alcohol (PVA) nanofibres via electrospinning. Biotechnology Reports, 10, 44-48.

21. Sheldon R. \& Rantwijk, F. 2004. Biocatalysis for Sustainable Organic Synthesis. Australian Journal of Chemistry, 57, 281-289.

22. Sidhu, G.S., Sharma, P., Chakrabarti, T. \& Gupta, J. K. 1997. Strain improvement for the production of a thermostable $\alpha$-amylase. Enzyme and Microbial Technology, 21(7): 525-530.

23. Taher, H., Al-Zuhair, S., Al-Marzouqi, A.H., Haik, Y. \& Farid, M.M. 2011. A review of enzymatic transesterification of microalgal oil-based biodiesel using supercritical technology. Enzyme Research, 4, 1-25.

24. Tanksale, A., Chandra, P.M., Rao, M. \& Deshpande, V. 2001. Immobilization of alkaline protease from Conidiobolus macrosporus for reuse and improved thermal stability. Biotechnology Letters, 23(1): 51-54.

25. Wang, Z.G., Wan, L.S., Liu, Z.M., Huang, X.J. \& Xu, Z.K. 2009. Enzyme immobilization on electrospun polymer nanofibers: an overview. Journal of Molecular Catalysis B: Enzymatic, 56(4): 189-195.

26. Zaborsky, O.R. 1973. Immobilized Enzymes. CRC Press, Cleveland, $\mathrm{OH}$. 